\title{
KAJIAN TEKNIS TIANG PANCANG KONSTRUKSI PILE SLAB PADA PROYEK JALAN TOL JKC STA 37+816.7 - 38+016.7
}

\author{
Dovi Adiwijaya $^{1}$, Aniek Prihatiningsih ${ }^{2}$ dan Josephine Aristiti Setyarini ${ }^{3}$ \\ ${ }^{1}$ Program Studi Sarjana Teknik Sipil, Universitas Tarumanagara, Jl. Letjen S. Parman No.1 Jakarta \\ Email: doviadiwijaya@yahoo.com \\ ${ }^{2}$ Program Studi Sarjana Teknik Sipil, Universitas Tarumanagara, Jl. Letjen S. Parman No.1, Jakarta \\ Email: aniekprihatiningsih@gmail.com \\ ${ }^{3}$ Program Studi Sarjana Teknik Sipil, Universitas Tarumanagara, Jl. Letjen S. Parman No.1, Jakarta \\ Email: Josephine.setyarini@gmail.com
}

\begin{abstract}
ABSTRAK
Pemancangan tiang pada konstruksi pile slab dengan fondasi tiang pancang ukuran diameter 0.6 meter dapat dilakukan dengan sistem preboring ataupun tanpa preboring dikarenakan alasan faktor sosial dan lingkungan. Fondasi tiang pancang harus berada pada kedalaman tanah keras dan mampu mendukung beban sampai batas keamanan yang telah ditentukan, termasuk mendukung beban maksimum yang mungkin terjadi. Proses pemancangan tiang menghasilkan data berupa jumlah pukulan dan final set dari hasil kalendering. Analisis daya dukung tiang pancang menggunaka metode statis dalam tulisan ini yaitu Meyerhof 1976 dengan menggunakan data SPT dan metode dinamik antara lain Modified ENR, Danish Formula, Janbu's Formula, dan Michigan State Highway Commission Formula dengan menggunakan data kalendering. Terdapat tes PDA serta program Allpile sebagai data untuk memverifikasi daya dukung tiang pancang. Kajian secara teknis konstruksi pile slab dengan fondasi tiang pancang pada STA 37+826.7-STA 38.016.7 jalan Tol Jakarta - Kunciran Cengkareng sehingga fondasi tiang tersebut dapat dikatakan efisien dan aman dilihat dari kedalaman tiang dan kapasitas daya dukung tiang.
\end{abstract}

Kata kunci: daya dukung tiang pancang, final set, jumlah pukulan, kalendering, N-SPT, PDA

\section{PENDAHULUAN}

\section{Latar belakang}

Pembangunan konstruksi jalan tol salah satunya didukung oleh fondasi yang dapat menahan beban dari jalan itu sendiri maupun beban kendaraan yang melewati jalan tersebut. Salah satu lokasi proyek jalan tol Jakarta - Kunciran - Cengkareng pada STA 37+826.7 - STA 38+016.7 di daerah Cipete dipilih untuk menggunakan fondasi tiang pancang dengan ukuran diameter $60 \mathrm{~cm}$.

Pelaksanaan pembuatan fondasi untuk infrastruktur jalan tol Jakarta - Kunciran - Cengkareng di Cipete terdapat beberapa faktor yang perlu diperhatikan seperti faktor lingkungan, faktor sosial, dan juga faktor biaya. Faktor faktor tersebut sangat memungkinkan dapat merubah rancangan yang telah ditentukan sejak awal, dimana perubahan yang terjadi terdapat pada perubahan sistem pemancangan yang awalnya tanpa sistem preboring menjadi dengan sistem preboring, kedalaman tiang pancang, jumlah pukulan hammer yang akhirnya mempengaruhi daya dukung dari tiang tunggal.

Adanya perubahan - perubahan tersebut membuat perlu dilakukannya kajian teknis terhadap jumlah pukulan terhadap kedalaman dan nilai N-SPT serta analisa daya dukung tiang pancang berdasarkan data - data penyelidikan tanah yang diperoleh di lapangan yaitu data SPTdan kalendering / final set dengan menggunakan metode yang disarankan oleh para ahli serta PDA tes dan program Allpile. Konstruksi fondasi tiang pancang pile slab dapat dikatakan aman jika daya dukung fondasi lebih besar dari beban jalan dan kendaraan yang dipikulnya dan fondasi berada pada kedalaman tanah keras.

\section{Tujuan}

Tujuan dari penelitian ini adalah untuk mengkaji secara teknis apakah konstruksi pile slab dengan menggunakan fondasi tiang pancang pada STA 37+826.7 - STA 38+016.7 lokasi proyek jalan tol Jakarta - Kunciran - 
Cengkareng di Cipete dapat dikatakan efisien dan aman secara struktur dilihat dari jumlah pukulan, selisih jumlah pukulan, serta daya dukung tiang pancang berdasarkan data N-SPT, final set / kalendering, dan PDA.

\section{Batasan masalah}

Dalam penelitian kali ini, terdapat beberapa batasan masalah yang akan dibahas, antara lain yaitu data penyelidikan tanah diperoleh dari 4 data titik boring yang dilakukan pada tahun 2017, lokasi yang ditinjau adalah STA 37+826.738+016.7, kajian teknis jumlah pukulan dan selisih jumlah pukulan terhadap kedalaman dan nilai N-SPT, digunakan juga metode Meyerhof (1976), metode Modified New ENR, Danish Formula, Janbu's Formula, Michigan State Highway Commission Formula dan berdasarkan data tes PDA (Pile Driving Analyzer) serta program Allpile untuk menghitung daya dukung aksial tiang, serta metode pemancangan tiang yang dianalisis adalah tanpa dan dengan preboring.

\section{DASAR TEORI}

Kajian teknis tiang pancang konstruksi pile slab pada proyek Jalan Tol Jakarta - Kunciran - Cengkareng STA 37+826.7-38+016.7 mengacu pada beberapa hal antara lain, jumlah pukulan, selisih jumlah pukulan, dan perhitungan daya dukung aksial menggunakan beberapa metode.

\section{Jumlah Pukulan \& Selisih Jumlah Pukulan}

Jumlah pukulan akan semakin besar apabila pemancangan tiang akan mencapai tanah keras. Berdasarkan kebiasaan jumlah pukulan ditentukan 2000 - 2500 pukulan, namun pada saat pelaksanaan di lapangan jumlah pukulan bisa berubah karena jumlah pukulan harus dibatasi untuk menghindari overdriving yang akan berdampak pada kerusakan struktur tiang.

Selisih jumlah pukulan tiang dapat dikatakan sudah berada atau mencapai kedalaman tanah keras pada saat penggurangan yang didapat dari pencatatan jumlah pukulan tiang pada kedalaman tanah keras yang telah dicapai dengan dikurangi dengan jumlah pukulan tiang 0.5 meter sebelumnya semakin membesar, namun selisih kedalaman tiang yang dipancang semakin kecil.

\section{Meyerhof 1976}

Perhitungan daya dukung dengan metode Meyerhof 1976 digunakan data hasil SPT, adalah sebagai berikut:

\section{Tanah non-kohesif}

○ Daya dukung ujung tiang

○ Daya dukung selimut tiang

$$
\mathrm{Qp}=40 \times \mathrm{N} \times \frac{L b}{D} \times \mathrm{Ap}
$$

$$
\text { Qs }=2 \times \mathrm{N} \times \mathrm{p} \times \mathrm{Li}
$$

dengan $\mathrm{N}=$ nilai $\mathrm{N}$ yang telah dikoreksi, $\mathrm{Li}=$ panjang lapisan tanah, $\mathrm{p}=$ keliling tiang, dan $\mathrm{Ap}=$ luas penampang tiang.

\section{Tanah kohesif}

○ Daya dukung ujun tiang

- Daya dukung selimut tiang

$$
\begin{aligned}
& \mathrm{Qp}=9 \times \mathrm{Cu} \times \mathrm{Ap} \\
& \mathrm{Qs}=\alpha \times \mathrm{Cu} \times \mathrm{p} \times \mathrm{Li}
\end{aligned}
$$

dengan $\mathrm{Ap}=$ luas penampang tiang, $\mathrm{Cu}=$ kohesi undrained, $\alpha=$ koefisien adhesi antara tanah dan tiang, $\mathrm{p}=\mathrm{keliling}$ tiang, $\mathrm{Li}=$ panjang lapisan tanah.

\section{Modified ENR}

Perhitungan daya dukung menggunakan metode Modified ENR merupaakn perhitungan daya dukung dinamik menggunakan data hasil kalendering.

$$
Q u=\frac{e_{h} W_{r} h\left(W_{r+n^{2}} W_{p}\right)}{(s+0,25)\left(W_{r}+W_{p}\right)}
$$

dengan $\mathrm{e}_{\mathrm{h}}=$ efisisensi hammer, $\mathrm{W}_{\mathrm{r}}=$ berat hammer, $\mathrm{h}=$ tinggi jatuh ram $(\mathrm{cm}), \mathrm{s}=$ penetrasi pukulan per $\mathrm{cm}, \mathrm{n}=$ koefisien restitusi antara ram dan pile, dan $\mathrm{W}_{\mathrm{P}}=$ berat tiang. 


\section{Danish Formula}

Metode perhitungan dinamik menggunakan Danish Formula memerlukan data hasil kalendering di lapangan.

dimana nilai $C_{1}=\sqrt{\frac{E_{h \times E_{h} \times L}}{2 \times A p \times E}}$

$$
Q u=\frac{\omega_{h \times E_{h}}}{s+C_{n}}
$$

dengan $\mathrm{e}_{\mathrm{h}}=$ efisiensi hammer, $\mathrm{E}_{\mathrm{h}}=$ energi hammer, $\mathrm{s}=$ penetrasi pukulan per $\mathrm{cm}, \mathrm{L}=$ panjang tiang, $\mathrm{E}=$ modulus elastisitas tiang, dan Ap = luas penampang tiang.

\section{Janbu's Formula}

Data kalendering dibutuhkan dalam menghitung daya dukung aksial tiang menggunakan metode ini

$$
Q u=\frac{E_{h} E_{h 2}}{K v_{r a}}
$$

$$
\begin{aligned}
& \text { dimana : } \quad K_{u}^{\prime}=C_{d}\left(1+\sqrt{1+\frac{\lambda^{r}}{c_{d}}}\right) \\
& C_{d}=0.75+0.14\left(\frac{W_{p}}{W_{r}}\right) \\
& \lambda^{\prime}=\frac{E_{h} E_{h} L}{A_{p} E s^{2}}
\end{aligned}
$$

dengan $\mathrm{e}_{\mathrm{h}}=$ efisiensi hammer, $\mathrm{E}_{\mathrm{h}}=$ energi hammer, $\mathrm{s}=$ penetrasi pukulan per $\mathrm{cm}, \mathrm{W}_{\mathrm{r}}=$ berat hammer, $\mathrm{W}_{\mathrm{P}}=$ berat tiang, $\mathrm{E}=$ modulus elastisitas tiang, dan Ap = luas penampang tiang.

\section{Michigan State Highway Cimmission Formula}

Sama seperti metode dinamik lainnya, metode ini juga membutuhkan data kalendering dalam perhitungannya

$$
Q_{u}=\frac{1.25 e_{h E_{h}}}{s+C} \times \frac{W_{T}+n^{2} W_{p}}{W_{T}+W_{p}}
$$

dengan $\mathrm{e}_{\mathrm{h}}=$ efisiensi hammer, $\mathrm{E}_{\mathrm{h}}=$ energi hammer, $\mathrm{s}=$ penetrasi pukulan per $\mathrm{cm}, \mathrm{W}_{\mathrm{r}}=$ berat hammer, $\mathrm{W}_{\mathrm{P}}=$ berat tiang, dan $\mathrm{C}=0.1$ in.

\section{METODE PENELITIAN}

Untuk mencapai tujuan dari penelitian ini, maka dilakukan beberapa tahapan yang dimana dimulai dengan melakukan studi literatur melalui buku, jurnal, dan webside. Pengumpulan data dilakukan setelah proses studi literatur yang mana pada tahapan ini data yang dikumpulkan adalah berdasarkan hasil peninjauan langsung di lapangan dengan melakukan pengamatan, pencatatan serta wawancara, data - data tersebut antara lain data hasil tes SPT, data pemancangan tiang, dan data kalendering.

Proses pengelolahan data menggunakan program Microsoft Excel, dimana dengan program tersebut data akan diolah dan dibentuk dalam grafik sehingga kajian data yang selanjutnya digunakan untuk analisis dan perhitungan dapat dilakukan dengan lebih mudah. Proses penelitian dapat dilihat lebih jelas dalam diagram alir pada gambar 1 berikut 


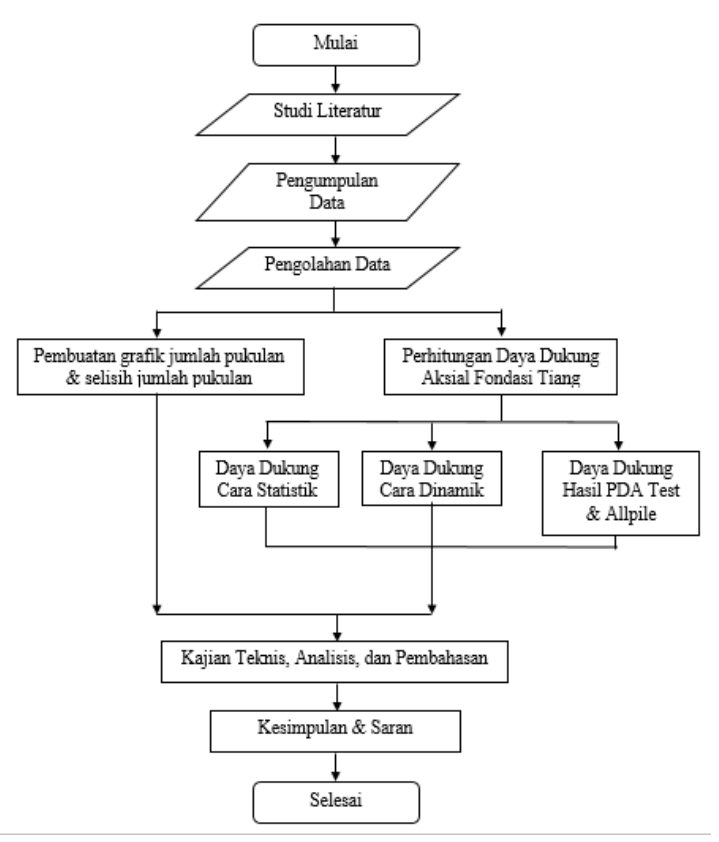

Gambar 1. Diagram Alir Penelitian

\section{KAJIAN TEKNIS}

Sebelum dilakukan kajian teknis untuk lebih mempermudah dalam mengkaji, menganalisis, dan membahas, maka STA 37+826.7-38+016.7 sepanjang $\pm 1 \mathrm{~km}$, dibagi menjadi beberapa zona dimana pembagian zona ini didasarkan pada lokasi titik borlog yaitu zona A (PS 1-10) mewakili BL47RW5, zona B (PS 11-17) mewakili BL47D, zona C (PS 18-24) mewakili BL47RW4, dan zona D (PS 25-31) mewakili BL47RW3.

\section{Kajian teknis jumlah pukulan}

Dalam hal ini kajian teknis jumlah pukulan dilihat dari hubungan jumlah pukulan dengan kedalaman dan juga nilai N-SPT.

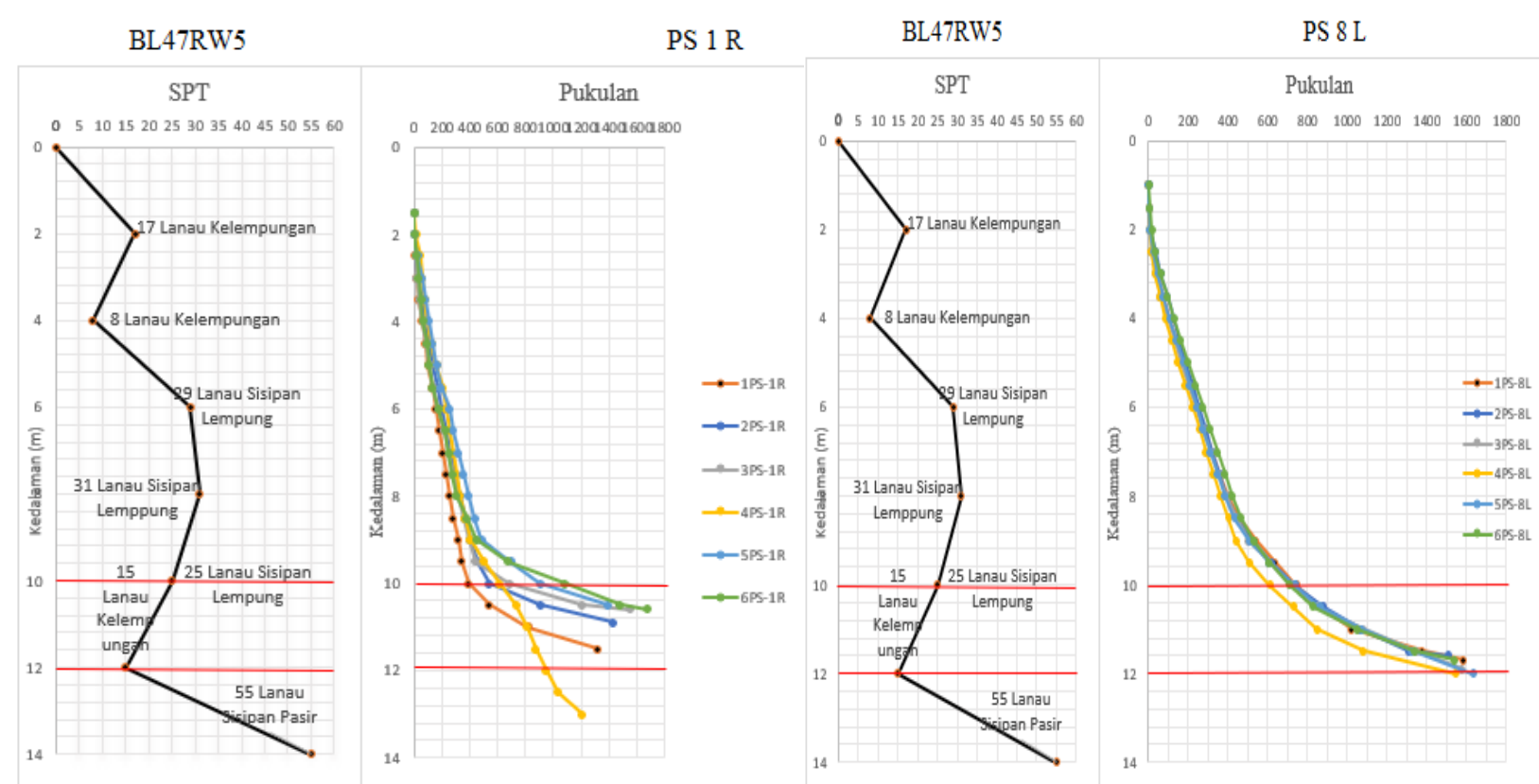

Gambar 2. Grafik Hubungan Jumlah Pukulan, Kedalaman, dan N-SPT tiang PS1R (non-preboring) dan tiang PS8L (preboring) 
Zona A : Pelaksanaan proses pemancangan pada zona A dilakukan dengan sistem tanpa preboring dan sistem dengan preboring. Pada tiang yang proses pelaksanaannya tanpa preboring diperoleh jumlah pukulan $1300-1500$ pukulan untuk mncapai kedalaman $10-12$ meter dengan jenis tanah lempung konsistensi sangat kaku yang memiliki nilai N-SPT rata - rata dan diperoleh jumlah pukulan 200 - 800 pukulan. Pengunaan sistem preboring tidak menjamin $100 \%$ bahwa jumlah pukulan yang dihasilakn akan lebih sedikit, hal ini dikarenakan terdapat data pada proyek jalan tol JKC STA 37+826.7-38+016.7 zona A yang walaupun pengerjaannya menggunakan sistem preboring namun jumlah pukulan yang dihasilkan hampir sama dengan jumlah pukulan tiang yang pelaksanaannya tanpa preboring.

Zona B : Pemancangan tiang pada zona B seluruhnya dilakukan dengan sistem preboring. Pada zona ini terdapat perbedaan jumlah pukulan yang dihasilkan pada PS right dengan PS left, dimana PS 11-17 right memiliki jumlah pukulan 500-800 pukulan dan berada pada kedalaman 11-12 meter dengan jenis tanah lempung konsistensi keras yang memiliki N-SPT = 35. Sedangkan tiang pada PS 11-17 left memiliki jumlah pukulan 700-1400 pukulan dan berada pada kedalaman 13-14 meter dengan jenis tanah kerikil sisipan lanau berkonsistensi sangat padat dengan nilai N-SPT rata - rata $=60$.

Zona C : Tiang - tiang yang berada pada zona $\mathrm{C}$ pemancangannya dilakukan dengan sistem preboring dan berada pada kedalaman 11 - 14 meter yang berjenis tanah pasir berkonsistensi sangat padat dan keras dengan nilai N-SPT rata - rata $=50$ menghasilkan jumlah pukulan 600-1100 pukulan.

Zona D : Tiang - tiang pda zona D menghasilkan jumla pukulan 550-800 pukulan untuk mencapai tanah berjenis lanau kelempungan berkonsistensi keras yang memiliki nilai N-SPT rata-rata $=34$ dan berada pada kedalaman 1113 meter.

\section{Kajian teknis selisih jumlah pukulan}

Kajian teknis selisih jumlah pukulan dengan melihat hubungan selisih jumlah pukulan dengan kedalaman dan nilai N-SPT.

Zona A : Diperoleh selisih jumlah pukulan $\geq 300$ pukulan per 0.5 meter ketika mulai memasuki kedalaman tanah keras ketika mulai memasuki kedalaman 10-11 meter dengan sistem pemancangan tanpa preboring, dan diperoleh selisih jumlah pukulan \pm 100 - 250 pukulan tiap 0.5 meter ketika mulai memasuki tanah keras.

Zona B :Selisih jumlah pukulan \pm 300 tiap 0.5 meter diperoleh ketika tiang mulai memasuki tanah pada kedalaman 11-14 meter yang merupakan tanah berjenis lempung konsistensi keras dengan nilai N-SPT rata - rata $=35$.

Zona C : untuk mencapai jenis tanah berjenis pasir sangat padat yang berada pada kedalam 11 - 14 meter memiliki selisih jumlah pukulan selisih $\geq 400$ untuk mencapai kedalaman 0.5 meter.

Zona D : tiang mencapai tanah keras pada kedalaman 11 - 13 meter jumlah pukulan yang dibutuhkan untuk menembus kedalaman tiap 0.5 meter adalah $300-500$ pukulan.

\section{Analisis \& pembahasan daya dukung metode Meyerhof 1976}

Perhitungan kapasitas daya dukung tiang pancang dengan metode Meyerhof 1976 digunakan data nilai N-SPT dari borlog BL47RW5, BL47D, BL47RW4, dan BL47RW3, dimana salah satu contoh perhitungan menggunakan metode Meyerhf 1976 dapat dilihat pada tabel 1.

Bedasarkan data N-SPT BL47RW5 (zona A) diperoleh daya dukung pada kedalaman 10 meter sebesar 121.5 ton, pada kedalaman 11 meter adalah 126.4 ton, kedalaman 12 meter diperoleh daya dukung sebesar 128.9 ton, dan kedalaman 14 meter diperoleh daya dukung sebesar 205 ton.

Berdasarkan data BL47D (zona B) didapatkan daya dukung pada kedalaman 10 meter sebesar 56.9 ton, kedalaman 11 meter adalah 66.6 ton, 12 meter sebesar 75.1 ton, kedalaman 13 meter sebesar 235 ton, dan kedalaman 14 meter diperoleh daya dukung sebesar 266 ton.

Berdasarkan data BL47RW4 (zona C) didapatkan daya dukung pada kedalaman 11 meter sebesar 177 ton, 12 meter dan 13 meter sebesar 226 ton, dan kedalaman 14 meter diperoleh daya dukung sebesar 229 ton.

Berdasarkan data BL47RW3 (zona D) didapatkan daya dukung pada kedalaman 1 meter sebesar 113 ton, 12 meter sebesar 129 ton, dan kedalaman 13 meter sebesar 141 ton. 
Tabel 1. Perhitungan Daya Dukung Tiang Berdasarkan BL47RW5

\begin{tabular}{|c|c|c|c|c|c|c|c|c|c|c|c|}
\hline \multirow{2}{*}{$\begin{array}{l}\text { Depth } \\
\text { (m) }\end{array}$} & \multirow{2}{*}{ Lapisan Tanah } & \multirow{2}{*}{$\mathrm{N}$} & \multirow{2}{*}{\begin{tabular}{|c|}
$\mathrm{N}$ \\
Koreks \\
$\mathrm{i}$ \\
\end{tabular}} & \multirow{2}{*}{$\mathrm{Cu}$} & \multirow{2}{*}{ a } & \multicolumn{2}{|c|}{ Skin Friction (kN) } & \multirow{2}{*}{$\begin{array}{c}\text { End } \\
\text { Bearing } \\
\text { (kN) }\end{array}$} & \multirow{2}{*}{$\begin{array}{l}\text { Qull } \\
(\mathrm{kN})\end{array}$} & \multirow{2}{*}{$\begin{array}{r}\text { Qull } \\
\text { (ton) }\end{array}$} & \multirow{2}{*}{$\begin{array}{c}\text { Qall } \\
\text { (ton) }\end{array}$} \\
\hline & & & & & & Lokal & Kumvlatif & & & & \\
\hline 0 & Lempong Kelanauan & 0 & 0 & 0 & 1 & 0 & 0 & 0 & 0 & 0 & 0 \\
\hline 1 & Lempung Kelanavan & 10 & 7 & 39.4 & 1 & 74 & 74 & 100 & 174 & 17 & 7 \\
\hline 2 & Lanav Kelempungan & 17 & 11 & 66.9 & 0.8 & 95 & 169 & 170 & 339 & 34 & 14 \\
\hline 3 & Lanav Kelempungan & 13 & 9 & 51.2 & 0.9 & 82 & 251 & 130 & 381 & 38 & 15 \\
\hline 4 & Lanau Kelempungan & 8 & 5 & 31.5 & 1 & 59 & 310 & 80 & 390 & 39 & 16 \\
\hline 5 & Lanav Kelempungan & 20 & 15 & 89.3 & 0.6 & 97 & 407 & 227 & 634 & 63 & 25 \\
\hline 6 & Lanav Sisipan Lempung & 29 & 22 & 129 & 0.4 & 98 & 504 & 329 & 833 & 83 & 33 \\
\hline 7 & Lanav Sisipan Lempung & 30 & 25 & 150 & 0.4 & 99 & 603 & 381 & 984 & 98 & 39 \\
\hline 8 & Lanav Sisipan Lempung & 31 & 26 & 155 & 0.4 & 102 & 705 & 393 & 1098 & 110 & 44 \\
\hline 9 & Lanav Sisipan Lempung & 28 & 23 & 140 & 0.4 & 99 & 804 & 355 & 1159 & 116 & 46 \\
\hline 10 & Lanav Sisipan Lempung & 25 & 21 & 125 & 0.4 & 94 & 898 & 317 & 1215 & 121 & 49 \\
\hline 11 & Lanas Kelempungan & 20 & 18 & 105 & 0.5 & 99 & 996 & 267 & 1264 & 126 & 51 \\
\hline 12 & Lanau Kelempungan & 15 & 13 & 78.8 & 0.6 & 93 & 1089 & 200 & 1289 & 129 & 52 \\
\hline 13 & Lanav Kelempungan & 35 & 31 & 184 & 0.3 & 104 & 1193 & 467 & 1660 & 166 & 66 \\
\hline 14 & Lanau Sisipan Pasir & 55 & 48 & 289 & 0.2 & 122 & 1315 & 734 & 2050 & 205 & 82 \\
\hline 15 & Lanav Sisipan Pasir & 45 & 39 & 236 & 0.3 & 111 & 1427 & 601 & 2028 & 203 & 81 \\
\hline 16 & Lanav Sisipan Pasir & 30 & 26 & 158 & 0.4 & 104 & 1531 & 401 & 1931 & 193 & 77 \\
\hline 17 & Lanav Kelempungan & 35 & 31 & 184 & 0.3 & 104 & 1634 & 467 & 2102 & 210 & 84 \\
\hline 18 & Lanav Kelempungan & 40 & 35 & 210 & 0.3 & 109 & 1743 & 534 & 2277 & 228 & 91 \\
\hline 19 & Lanav Kelempungan & 50 & 44 & 263 & 0.2 & 111 & 1854 & 668 & 2522 & 252 & 101 \\
\hline 20 & Pasir Sedang \& Halus & 60 & 53 & & & 198 & 2052 & 989 & 3041 & 304 & 122 \\
\hline 21 & Pasir Sedang \& Halus & 54 & 47 & & & 178 & 2230 & 890 & 3121 & 312 & 125 \\
\hline 22 & Pasir Sedang \& Halus & 48 & 42 & & & 158 & 2389 & 791 & 3180 & 318 & 127 \\
\hline 23 & Pasir Sedang \& Halus & 35 & 31 & & & 115 & 2504 & 577 & 3081 & 308 & 123 \\
\hline 24 & Lanav Sisipan Lempung & 23 & 20 & 121 & 0.4 & 97 & 2601 & 307 & 2908 & 291 & 116 \\
\hline 25 & Lanav Sisipan Lempung & 20 & 18 & 105 & 0.5 & 99 & 2700 & 267 & 2967 & 297 & 119 \\
\hline
\end{tabular}

\section{Analisis \& pembahasan daya dukung metode Modified ENR}

Perhitungan dengan data kalendering di lapangan dengan metode Modified ENR berdasarkan persamaan (5) adalah sebagai berikut

$$
\begin{aligned}
Q u= & \frac{\theta_{h W r h\left(W r+n^{2} W p\right)}}{(s+0.25)(W r+W p)} \\
& =\frac{0.8 \times 5.5 \times 250 \times\left(5.5+0.4^{2} \times 10.852\right)}{(1.833+0.25) \times(5.5+10.852)} \\
& =233.7 \text { ton }
\end{aligned}
$$

Berdasarkan contoh perhitungan seperti diatas diperoleh jumlah tiang yang memenuhi syarat daya dukung aksial yaitu:

Tabel 2. Persentase Jumlah Tiang yang Memenuhi Syarat Daya Dukung Aksial Menurut Modified ENR

\begin{tabular}{|c|c|c|}
\hline Zona & $\begin{array}{c}\text { Jumlah Tiang Lolos } \\
(\%)\end{array}$ & $\begin{array}{c}\text { Total Jumlah Tiang } \\
\text { dalam Zona }\end{array}$ \\
\hline $\mathrm{A}$ & 96.7 & 120 \\
\hline $\mathrm{B}$ & 94.8 & 77 \\
\hline $\mathrm{C}$ & 100 & 71 \\
\hline $\mathrm{D}$ & 100 & 15 \\
\hline
\end{tabular}

\section{Analisis \& pembahasan daya dukung metode Danish Formula}

Perhitungan daya dukung dengan data hasil kalendering yang diperoleh di lapangan juga dapat dilakukan dengan metode Danish Formula berdasarkan persamaan (6) sebagai berikut

$$
\begin{aligned}
C_{1} & =\sqrt{\frac{E_{h S H_{h} H_{L} L}}{2 \times A \times E}} \\
& =\sqrt{\frac{0.8 \times 13.75 \times 16}{2 \times 0.2826 \times 30 \times 10^{5}}}=0.01018
\end{aligned}
$$




$$
\begin{aligned}
Q u & =\frac{e_{\text {hxe }_{h}}}{s+C_{1}} \\
& =\frac{0.8 \times 13.75}{0.01833+0.01018}=385.7 \text { ton }
\end{aligned}
$$

Berdasarkan contoh perhitungan seperti diatas diperoleh jumlah tiang yang memenuhi syarat daya dukung aksial yaitu:

Tabel 3. Persentase Jumlah Tiang yang Memenuhi Syarat Daya Dukung Aksial Menurut Danish Formula

\begin{tabular}{|c|c|c|}
\hline Zona & $\begin{array}{c}\text { Jumlah Tiang Lolos } \\
(\%)\end{array}$ & $\begin{array}{c}\text { Total Jumlah Tiang } \\
\text { dalam Zona }\end{array}$ \\
\hline $\mathrm{A}$ & 99.2 & 120 \\
\hline $\mathrm{B}$ & 100 & 77 \\
\hline $\mathrm{C}$ & 100 & 71 \\
\hline $\mathrm{D}$ & 100 & 15 \\
\hline
\end{tabular}

\section{Analisis \& pembahasan daya dukung metode Janbu's Formula}

Perhitungan menggunakan data kalendering dengan metode Janbu's Formula didasarkan pada persamaan (7), dengan perhitungan sebagai berikut

$$
\begin{aligned}
C_{\text {d }} & =0.75+0.14\left(\frac{W_{p}}{W_{r}}\right) \\
& =0.75+0.14\left(\frac{10.852}{5.5}\right)=1.026 \\
\lambda^{s} & =\frac{e_{h} E_{h} L}{A_{p} E s^{2}} \\
& =\frac{0.8 \times 13.75 \times 16}{0.2826 \times 30 \times 10^{5} \times\left(1.833 \times 10^{-2}\right)^{2}}=0.618 \mathrm{~m}
\end{aligned}
$$

$$
\begin{aligned}
K_{u s}^{s} & =C_{d}\left(1+\sqrt{1+\frac{\lambda^{s}}{C_{d}}}\right) \\
& =1.026\left(1+\sqrt{1+\frac{0.618}{1.026}}\right)=2.325
\end{aligned}
$$

$$
Q u=\frac{e_{h} E_{h}}{K^{v} s}
$$

$$
=\frac{0.8 \times 13.75}{2.325 \times\left(1.833 \times 10^{-2}\right)}=258.1 \text { ton }
$$

Berdasarkan contoh perhitungan seperti diatas diperoleh jumlah tiang yang memenuhi syarat daya dukung aksial yaitu: 
Tabel 4. Persentase Jumlah Tiang yang Memenuhi Syarat Daya Dukung Aksial Menurut Janbu's Formula

\begin{tabular}{|c|c|c|}
\hline Zona & $\begin{array}{c}\text { Jumlah Tiang Lolos } \\
(\%)\end{array}$ & $\begin{array}{c}\text { Total Jumlah Tiang } \\
\text { dalam Zona }\end{array}$ \\
\hline A & 98.3 & 120 \\
\hline B & 92.2 & 77 \\
\hline C & 100 & 71 \\
\hline D & 100 & 15 \\
\hline
\end{tabular}

\section{Analisis \& pembahasan daya dukung metode Michigan State Highway Commission Formula}

Berdasarkan pada persamaan (8) diperoleh hasil perhitungan daya dukung berdasarkan metode Michigan State Highway Commission Formula, dengan contoh perhitungan sebagai berikut

$$
\begin{aligned}
Q_{\mathrm{u}} & =\frac{1.25 e_{h E_{h}}}{s+C} \times \frac{W_{r}+n^{2} W_{p}}{W_{r}+W_{p}} \\
& =\frac{1.25 \times 0.8 \times 1375}{1.833+0.25} \times \frac{5.5+0.4^{2} \times 10.852}{5.5+10.852}=292.1 \text { ton }
\end{aligned}
$$

Berdasarkan contoh perhitungan seperti diatas diperoleh jumlah tiang yang memenuhi syarat daya dukung aksial yaitu:

Tabel 5. Persentase Jumlah Tiang yang Memenuhi Syarat Daya Dukung Aksial Menurut Michigan State Highway Commission Formula

\begin{tabular}{|c|c|c|}
\hline Zona & $\begin{array}{c}\text { Jumlah Tiang Lolos } \\
(\%)\end{array}$ & $\begin{array}{c}\text { Total Jumlah Tiang } \\
\text { dalam Zona }\end{array}$ \\
\hline A & 98.3 & 120 \\
\hline B & 94.8 & 77 \\
\hline C & 100 & 71 \\
\hline D & 100 & 15 \\
\hline
\end{tabular}

\section{Daya dukung berdasarkan data hasil PDA Test (Pile Driving Analyzer Test)}

Pengujian PDA test pada proyek jalan tol JKC dilakukan pada tiang 6 Blok-PS26R dan tiang 6 Blok-PS27R. berdasarkan hasil pengujian tes PDA, tiang pancang spun pile berdiameter 0.6 meter memiliki daya dukung sebagai berikut:

Tabel 6. Hasil PDA Test

\begin{tabular}{|c|c|c|c|c|}
\hline Tiang & $\begin{array}{c}\text { Qultimate } \\
\text { (ton) }\end{array}$ & $\begin{array}{c}\mathrm{Q}_{\text {all }} \mathrm{Fs}=2 \\
\text { (ton) }\end{array}$ & $\begin{array}{c}\text { Qall Fs }=2.5 \\
\text { (ton) }\end{array}$ & $\begin{array}{c}\mathrm{Q}_{\text {all }} \mathrm{Fs}=3 \\
\text { (ton) }\end{array}$ \\
\hline $\begin{array}{c}\text { 6 Blok-PS } \\
\text { 26R }\end{array}$ & 434 & 217 & 173.6 & 146.7 \\
\hline $\begin{array}{c}\text { 6 Blok-PS } \\
27 \mathrm{R}\end{array}$ & 461 & 230.5 & 184.4 & 153.7 \\
\hline
\end{tabular}

\section{Daya dukung berdasarkan data program Allpile}

Berdasarkan pada hasil perhitungan menggunakan program Allpile yang akan digunakan sebagai data perhtiungan untuk verifikasi diperoleh data sebagai berikut: 
Jurnal Mitra Teknik Sipil

Vol. 1, No. 1, Agustus 2018: hlm 19-28

\begin{tabular}{|c|c|}
\hline \multicolumn{2}{|c|}{ Zona A (BL47RW5) } \\
\hline Kedalaman (m) & Qull (ton) \\
\hline 10 & 155.7 \\
\hline 11 & 171.3 \\
\hline 12 & 186.9 \\
\hline 13 & 204.3 \\
\hline 14 & 221.7 \\
\hline \multicolumn{2}{|c|}{ Zona B (BL47D) } \\
\hline Kedalaman (m) & Qull (ton) \\
\hline 10 & 190.2 \\
\hline 11 & 204.6 \\
\hline 12 & 219 \\
\hline 13 & 232.5 \\
\hline 14 & 246 \\
\hline \multicolumn{2}{|c|}{ Zona C (BL47RW4) } \\
\hline Kedalaman (m) & Qull (ton) \\
\hline 10 & 59.7 \\
\hline 11 & 65.7 \\
\hline 12 & 71.7 \\
\hline 13 & 315.6 \\
\hline 14 & 243.3 \\
\hline \multicolumn{2}{|c|}{ Zona D (BL47RW3) } \\
\hline Kedalaman (m) & Quil (ton) \\
\hline 10 & 139.5 \\
\hline 11 & 153.6 \\
\hline 12 & 169.2 \\
\hline 13 & 184.2 \\
\hline 14 & 199.2 \\
\hline
\end{tabular}

\section{KESIMPULAN}

Berdasarkan kajian teknis, analisis, dan pembahasan dari proyek konstruksi jalan tol JKC, diperoleh kesimpulan sebagai berikut:

1. Total 188 tiang yang sudah dikerjakan dengan preboring dan 95 tiang dikerjakan tanpa preboring. Pemakaian metode pemancangan dengan preboring dilakukan karena faktor utama yaitu faktor sosial dan lingkungan.

2. Beradasarkan hubungan jumlah pukulan serta selisihnya dengan nilai N-SPT dan kedalaman, untuk tiang sejumlah 283 tiang yang sudah dikerjakan dari total keseluruhan tiang 468 yang berada pada STA $37+826.7$ - STA 38+016.7 telah mencapai lapisan tanah keras pada kedalaman $10-14$ meter.

3. Berdasarlan kajian teknis pada proses pemacangan tiang diproyek jalan tol Jakarta - Kunciran Cengkareng STA 37+826.7 - STA 38+016.7 tanpa preboring diperoleh nilai maksimum jumlah pukulan sebesar 2513 pukulan dan jumlah pukulan minimum adalah 712 dan dengan preboring diperoleh nilai maksimum jumlah pukulan sebesar 2412 pukulan dan jumlah pukulan minimum adalah 232 pukulan.

4. Pada zona A, tiang yang dikerjakan tanpa preboring memiliki selisih jumlah pukulan $\geq 30$ pukulan per 0.5 meter dan tiang yang dikerjakan dengan sistem preboring memiliki selisih jumlah pukulan $\pm 100-250$ pukulan per 0.5 meter ketika memasuki kedalaman tanah lempung atau lanau dengan konsistensi sangat kaku yang memiliki nilai rata - rata $\mathrm{N}-\mathrm{SPT}=20-23$.

5. Pada proyek jalan tol Jakarta - Kunciran - Cengkareng di Cipete STA 37+826.7 - STA 38+016.7 zona B, $C$, dan D yang pelaksanaanya menggunakan sistem preboring memiliki selisih jumlah pukulan $\pm 300-500$ pukulan per 0.5 meter untuk mencapai kedalaman tanah keras dengan jenis tanah lempung atau lanau dengan konsistensi sangat kaku yang memiliki nilai N-SPT 20 - 35, sedangkan untuk mencapai kedalaman tanah keras berjenis tanah pasir dengan konsistensi sangat padat / keras yang memiliki nilai N-SPT 30 sampai $\geq 50$ memiliki selisih jumlah pukulan $\geq 400$ pukulan per 0.5 meter.

6. Gambar 3 memperlihatkan hasil perhitungan dengan data N-SPT menggunakan metode Meyerhof 1976 dan program Allpile memiliki hasil berbeda jauh dengan data hasil tes PDA. 


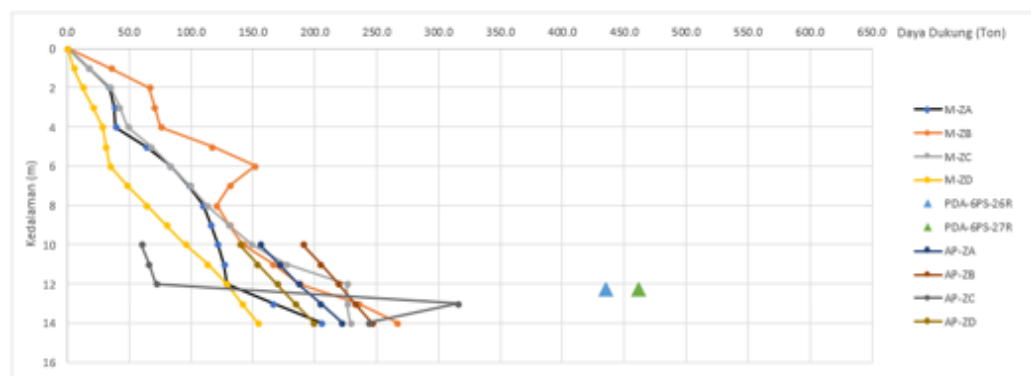

Gambar 3. Grafik Hasil Perhitungan Daya Dukung Aksial Menggunakan Meyerhof 1976, PDA test, dan Allpile

7. Daya dukung dari 283 tiang yang sudah dikerjakan berdasarkan metode Meyerhof 1976 sebanyak $100 \%$ tiang memenuhi daya dukung aksial. Untuk metode Modified ENR sebanyak $97.5 \%$ tiang dari 283 tiang memenuhi daya dukung aksial. Menurut metode Danish Formula dan Janbu's Formula sebanyak 99.6\% dan $97.2 \%$ dari 283 tiang memenuhi daya dukung aksial. Sedangkan sebanyak $98.2 \%$ tiang memenuhi daya dukung aksial menurut metode Michigan State Highway Commission Formula. Data dari program Allpile menunjukan sebnayak $92.7 \%$ tiang memenuhi daya dukung aksial diang dan data dari hasil PDA tes menunjukan tiang 6 Blok - PS 26R dan 6 Blok - PS 27R memenuhi daya dukung aksial tiang.

8. Terdapat beberapa data yang tidak sesuai disebabkan oleh beberapa hal seperti proses pelaksanaan pemancangan tiang yang tidak diawasi oleh tenaga ahli yang memahami tentang geoteknik dan juga sifat tanah yang tidak terduga (unpredictable).

\section{DAFTAR PUSTAKA}

Bowles, Joseph E. 1988. Analisa dan Desain Pondasi Jilid 1. Edisi Keempat. Jakarta: Penerbit Erlangga. (Diterjemahkan oleh: Pantur Silaban, Ph.D).

Das, Braja M. 1995. Mekanika Tanah (Prinsip - Prinsip Rekayasa Geoteknis) Jilid 2. Jakarta: Penerbit Erlanga. (Diterjemahkan Oleh: Noor Endah dan Indrasurya B. Mochtar)

Das, Braja M. 1999. Principles of Geotechnical Engineering Fourth Edition. Canada: Thomson Canada Limited.

Das, Braja M. 2007. Principles of Foundation Engineering Sixth Edition. Canada: Thomson Canada Limited.

Das, Braja M. 2011. Geotechnical Engineering Handbook. USA: J.Ross Publishing, Inc.

Hardiyatmo, Hary Christady. 2008. Teknik Pondasi 2. Jakarta: Gramedia Pustaka Utama.

Hardiyatmo, Hary Christady. 2011. Analisis dan Perancangan Fondasi I. Edisi Kedua. Yogyakarta: Gadjah Mada University Press.

Kurniadi, Akbar, Imam Faizal Rosyidin, Himawan Indarto, dan Indrastono Dwi Atmono. 2015. Desain Struktur Slab on Pile. Semarang: Jurnal Karya Teknik Sipil. Vol. 4, No. 4:57-68. (http://download.portalgaruda.org/article.php?article=364555\&val=4693\&title=DESAIN\%20STRUKTUR\% 20SLAB\%20ON\%20PILE. Diakses pada 28 Juni 2018).

NPTEL-Advanced Foundation Engineering I. 2013. Modul 8 (Lecture 33) Pile Foundation. NPTEL-Advanced Foundation Engineering I.

Rahman, Md Manzur. 2018. Foundation Design using Standard Penetration Test (SPT) N-value. (https://www.researchgate.net/publication/318110370. Diakses pada 6 Maret 2017).

Sandjaja, Gregorius. 2015. Diktat Pondasi Tiang II. Jakarta: Universitas Tarumanagara.

Siregar, Christina R, serta Rudi Iskandar. Analisa Daya Dukung Pondasi Tiang Pancang Secara Analitis pada Proyek GBI Bethel Medan. (http://download.portalgaruda.org/article.php?article=58875\&val=4146. Diakses pada 7 Febuari 2018).

Sosrodarso, S dan Kazuto Nakazawa. 1981. Mekanika Tanah \& Teknik Pondasi. Jakarta: PT Pradaya Paramita. (Diterjemahkan oleh: Ir. L. Taulu dkk).

Teng. Wayne C. 1977. Foundaton Design. New Delhi: Prentice Hall of India

Terzaghi, Karl dan Ralph B. Peck. 1987. Mekanika Tanah dalam Praktek Rekayasa Jilid 1. Edisi Kedua. Jakarta: Penerbit Erlangga.

Terzaghi, Karl dan Ralph B. Peck. 1991. Mekanika Tanah dalam Praktek Rekayasa Jilid -2. Edisi Kedua. Jakarta: Penerbit Erlangga. 